\title{
Participatory Budgeting in Bangladesh Local Government Context
}

\author{
A. N. M. Zakir Hossain ${ }^{1}$, Anwara Begum ${ }^{2}$, Muhammad Shafiul Alam² \& Md. Shahidul Islam ${ }^{3}$ \\ ${ }^{1}$ Department of Agricultural Economics, Bangladesh Agricultural University (BAU), Mymensingh, Bangladesh \\ ${ }^{2}$ Department of Public Administration, Shahjalal University of Science and Technology (SUST), Sylhet, \\ Bangladesh \\ ${ }^{3}$ Department of Sociology, Shahjalal University of Science and Technology (SUST), Sylhet, Bangladesh \\ Correspondence: A.N.M. Zakir Hossain, Department of Agricultural Economics, Bangladesh Agricultural \\ University (BAU), Mymensingh, Bangladesh. Tel: 88-017-1658-1955. E-mail: anmzakirhossain@bau.edu.bd
}

\author{
Received: February 14, 2014 Accepted: February 24, 2014 Online Published: October 18, 2014 \\ doi:10.5539/par.v3n2p28 \\ URL: http://dx.doi.org/10.5539/par.v3n2p28
}

\begin{abstract}
This study aims to examine the spaces for citizen participation in the municipal budgeting process and to access the extent of citizen participation in local government decision-making with specific focus on citizen participatory budgeting in Bangladesh. A cross-sectional study was conducted in Nabigonj Municipality of Habigonjin Bangladesh. Both social survey method and in-depth interview have been applied for collecting data from the respondents in the study area. The findings asserted that level of scope of participations was very low in this area but the majority (55.3\%) of people was highly positive about the initiation to (Participatory Budgeting) PB. This study also reveals that understanding of participatory budgeting as a concept that leads to improve governance is still very limited and Citizens were incapable of contributing productively to policy-making within the Nabigonj Municipality.
\end{abstract}

Keywords: participatory budgeting, local government, good governance, Bangladesh

\section{Introduction}

Participatory budgeting (PB) is an approach of direct democracy to budgeting which offers citizens an opportunity to learn about government operations and to deliberate, debate, and influence the allocation of public resources (Shah, 2007). In the modern world where Good Governance is the central issue of sustainable development, the concept participatory management has gained enormous popularity and is getting immense importance in developing countries (from both national and international forces) during the last few decades and more. Governance reform has emerged as a key concept shaping all debates and discourses on development in recent years, significantly impacting the dynamics of policy making as well as the implementation of development programs and public accountability. Now-a-days, governance system gives more emphasis on decentralization and strengthening local government (Murdia, 2005).More generally, the recent emphasis on good governance as the foundation for sustained and equitable development has generated a widespread interest in participation in the development circle. In terms of effective participation by all stakeholders, especially at local levels of government, it has come to be viewed as a necessary condition for promoting good governance. In every place, decentralization is said to contribute to democratization by dispersing legitimate political authority, bringing the government 'closer to the people'. It offers opportunities for political education through citizen participation in local management and making governments more accountable (Canel, 2001). The countries that are involved in democracy and local development, participatory budgeting (PB) is a central topic of discussion and significant field of innovation. This participatory approach marks a significant advance in democratizing local politics and establishing a new modality of urban governance that facilitates the emergence of practices of citizenship.

PB is a platform that provides opportunities for making better decision through debate and consensus building with all concern stakeholders. Municipalities are currently experiencing a period of dynamic change around the world by influencing the trend of decentralization and democratization of governments. This helps to develop decision making powers and responsibilities thus results more accountability. Participatory budgets (PBs) are emerging as a paradigm for participation, especially at local level; (Sintomer et al., 2008) and are becoming increasingly popular in many other places, all around the world. Participatory budgeting (PB) is a unique 
democratic innovation that was first implemented in 1989 by the governing Worker's Party (Partido dos Trabalhadores - PT) in the city of Porto Alegre, Brazil (Nieuwland, 2003) to overturn Brazil's long history of patronage politics, social inequity, and corruption. Government, civil society and political parties mobilized to experiment with participatory budgeting as a way to improve government transparency, accountability and increase citizen voice in government decisions (World Bank, 2006). The system strives to involve the general populace in the prioritization and allocation of local resources outlined in the yearly city budget, with the primary goal of redistributing these resources from the advantaged to the disadvantaged (Santos, 1998).It also provides a meaningful and effective citizen participation in public choices that improves trust in government and commitment to the trade-off made. Together with improved budget transparency and accountability, participation can build social cohesion, which can lead to the very tangible benefit of increased tax collection (Shah, 2007) for steady development. PB is expected to add few input to conventional budgetary practice by bringing elected representatives and citizens together, however the review show that sometimes it faces few challenges (i.e.; lack of participation of extreme poor, participation of young) and make policy-makers able to provide goods and services and to develop policies that better match public preferences on the road to strengthen political accountability as it works as a commitment device for the elected politicians. So participation has become a "hot" issue and a buzzword in the planning of local programs as well as in their financing.

\subsection{Statement of the Problem}

In the modern competitive world where the demands and expectations of the citizens are raising day by day, the government has to gain the ability to meet the demands and expectations with changing time to ensure the sustainability and development through governance. Bangladesh as a resource poor country where there is no direct participation in decision making processes at all level of government, needs a governance in which the local government body allows the citizens to participate in formulating and implementing the development budget, plans and policies that produce the modern facilities for them. The purpose of the study is to explore and identify the opportunities and constraints of participatory budgeting in local government body that help to promote the sustainable use of resources for their development.

\subsection{Justification of Research}

As the concept participatory budgeting is now being related to the rights of citizens, democratic governance and poverty alleviation, there are several arguments in favor of the relevance of the present research.

First, the research contributes to the increasing body of knowledge about the factors leading to success or failure in participatory budgeting for participatory democracy. Although participatory budgeting is not currently the management approach for local government of the country, this research assessed the factors potentially hindering the development of such a management approach. More specifically, the present research contributes to a better understanding about the communal and organizational settings that leads to effective participatory budgeting and successful community-based resources management.

Second, the research findings have potential for practical application. It provides support for the adequacy of the status of local area, looking for the establishment of a more legitimate and sounds participatory budgeting. The research has implications for the defense of necessity and potentiality of participatory budgeting. The present research contributes to the understanding of problems and prospects of participatory budgeting, especially in the context of developing countries.

Finally, the purpose of this study is not only to create a model capable of fulfilling the promises of participatory budgeting (a more just distribution of resources and greater citizen involvement); the purpose is also to set a research agenda that will test and refine the theories under investigation.

\subsection{Review of Relevant Literature}

Participatory budgeting $(\mathrm{PB})$ reflects a direct democratic approach to budgeting. It provides an authoritative guide to the principles and practices of participatory budgeting that offers citizens at large an opportunity to learn about government operations and deliberate, debate and influence the allocation of public resources. It also talk about how PB works as a tool that strengthening the demand for good governance by citizens education, engagement and empowerment (Shah, 2007). It also explores transparency and accountability can reduce government inefficiency, waste and curb clientele-ism, patronage and corruption that brought about by PB. Governance inclusively strengthen by PB because it provides the opportunity for the marginalized and excluded groups of the society to have their voices heard and influence public decision making that is vital to their interests. Shah (2007) also said about the governance which is more responsive to citizens needs and accountable to them for performance in resource allocation and service delivery and can enhance the quality of democratic 
participation. He provides a careful analysis of potentials and perils of participatory budgeting as observed from practices around the globe (Shah, 2007).

Local councils as unit of decentralized local government produce improved service delivery and sustainable development by promoting effective participation of all stakeholders in planning and decision making process. This paper also facilitates local councils to co-ordinate and lead to better consultation among stakeholders at all level. Local Government shall have the right and obligation to formulate, approve and execute their budgets and plans and that should be balanced. The budget is to plan and to implement the projects in order to bring about the development of the area considering the priority and resource availability (Ministry of Local Government, Uganda 2002).

The United Nations emphasizes on the people's participation at local level that it can be used as an instrument to ensure and increase the accountability of the public sector because participation has given the citizens greater opportunities to influence policy making as well as policy implementation process. According to the study Participatory Budgeting (PB) is a key dimension of good governance and appreciates local development initiatives with reduction of poverty and attainment of the Millennium Development Goals (MDGs). This paper also discuss about participatory budgeting in respect to various countries (i.e.: Bangladesh, Philippine, Indonesia, India etc) and their impact on them which help them to reduce poverty and ensure the effective service delivery to the citizens (UN, 2005).

Virapatirin and Peixoto, (2006) tries to describe the models and methods to support the elaboration of a participatory budget as these are becoming increasingly popular in many other municipalities, all around the world. Governments are paying special attention to promote citizen participation, especially at local level because participatory budgets are transforming the idea of a representative democracy where citizens' preferences are consideredand providing the opportunity to discuss budgetary issues and public policies, and make relevant decision.

Rios and Rios (2005) focuses on the process of budgeting that is different because convention participatory budgeting based on dialogue and citizen participation in which citizen has practically no opportunity to influence the council policies as they elected representatives for 5 years. In this paper, they will sketch a model and a web based system to support participatory budget elaboration processes. They focus on negotiation problem and use balanced increment method with budget constraints to support such negotiations. The paper indicates a web-based system to support groups in elaborating participatory budgets without physical meetings with voting mechanisms. They wish to promote virtual meetings with explicit preference elicitation, guided negotiations and voting when it fails to make consensus (Rios \& Rios, 2005). Convention

Availability of financial resources is a primary requirement for the implementation of projects (Chadha, 1989). He describes about the budgeting process, its schedule and terminology.Budget is an interpretation of annual activities based on the revenues and expenditures, expressed in financial terms and reflecting aspirations. The structure of local government in Bangladesh is complex, largely because of the shared responsibility between local and central governments for administering and financing different public sector functions. As Municipality is an autonomous body but it is seen as an agent of central government. It has many compulsory and optional functions with some specialized works. In comparison to the other local government institutions, like (Union Parishads) UPs, the municipalities have, to a large extent, survived and continued their maintenance of roads, provisions of park etc. The reason that they have survived with their functions can perhaps be attributed to their own resource base and also continued participatory character (Chadha, 1989).

\subsection{Objectives of the Research}

This study aims to examine the spaces for citizen participation in the municipal budgeting process in Bangladesh and it will also access the extent of citizen participation in local government decision-making with specific focus on citizen participatory budgeting.

The objectives of this study are:

1) To examine the problems faced by the local level government units of Bangladesh in participatory budgeting;

2) The causes and the consequences of such problems;

3) The study attempted to propose some policy or operational guidelines.

\subsection{Research Questions}

The following questions may be raised to conduct the research: 
1) What is the existing scenario of budget in municipality in Bangladesh?

2) To what extent the citizen participate in municipality budgeting?

3) Is there any institutional inadequacy for participatory budgeting?

4) What legislative measures should be developed?

\subsection{Conceptual Framework}

The conceptual framework of this research will test the implication of imposing participatory budgeting (PB) on municipal council. The conceptual framework for this study depicts the process of participatory budgeting to achieve the desired outcomes.

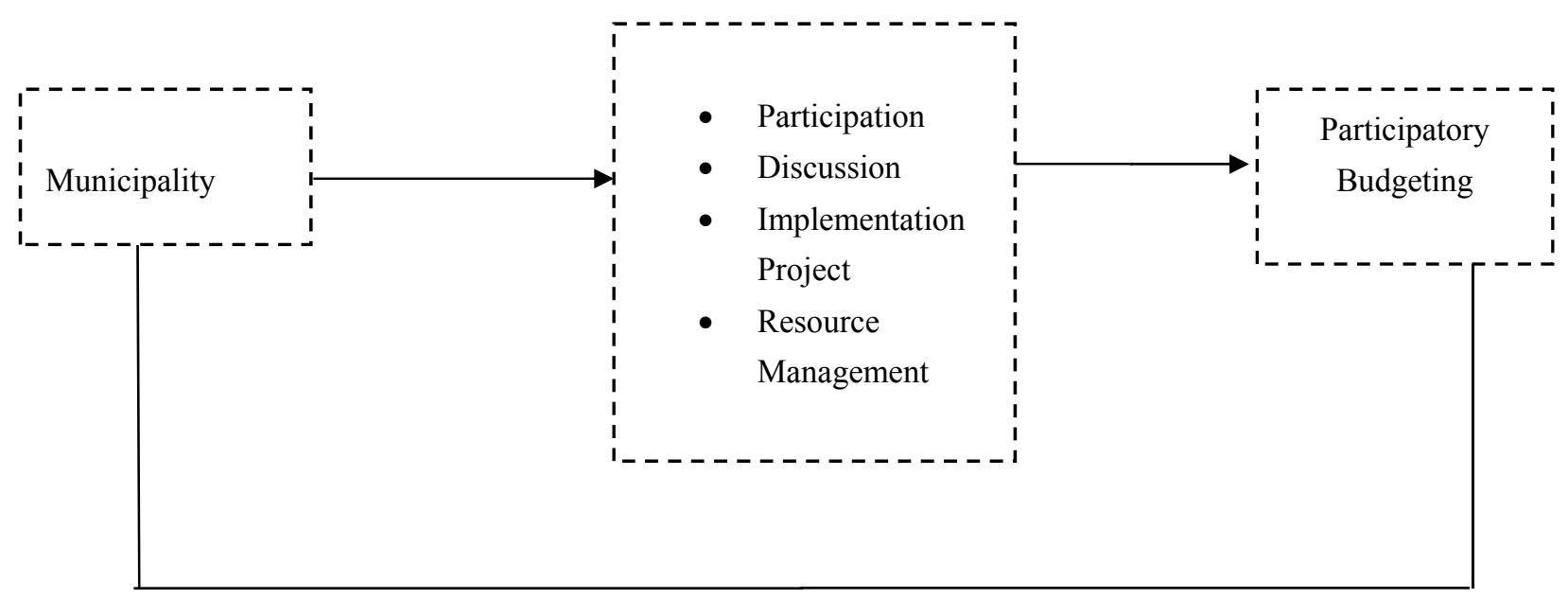

Figure 1. Conceptual framework

The conceptual framework of the study examined the implications of participatory budgeting at local level for increasing the effectiveness of local government of Bangladesh so as to increase the satisfaction of mass people. The conceptual framework for this research shows the process of participatory budgeting at local government level because the decentralized structure and the scope of decision making by the local government body will help to ensure the proper development at local level that is why it is needed for local people to give the space to make their own decisions that related to their local affairs and development.

The conceptual framework has been developed using key elements (variables) of participatory budgeting framework from reviewed literature. It attempts to show, how the independent variables may bring changes in dependent variables.

Moreover, this framework helps to develop the interview schedule by linking each question to the collection of data to answer the research questions.

\section{Methods}

\subsection{Research Design}

This was a cross-sectional study. Both quantitative and qualitative methods were used to achieve the objectives of the study. The methodological triangulation (social survey and in-depth interview) was used.The triangulation design have used because the strength of qualitative and quantitative each approach not only enrich the research credibility but also ensure more valid result.

\subsection{Study Area and Location}

Keeping view in the main objectives as well as time and resource constraints, Nabigonj Municipality of Hobigonj district was purposively selected for the study. This municipality consists of nine wards and 20 mahallas. This study area is well connected through the Dhaka-Sylhet high way and hence, congenial for field level data collection. 


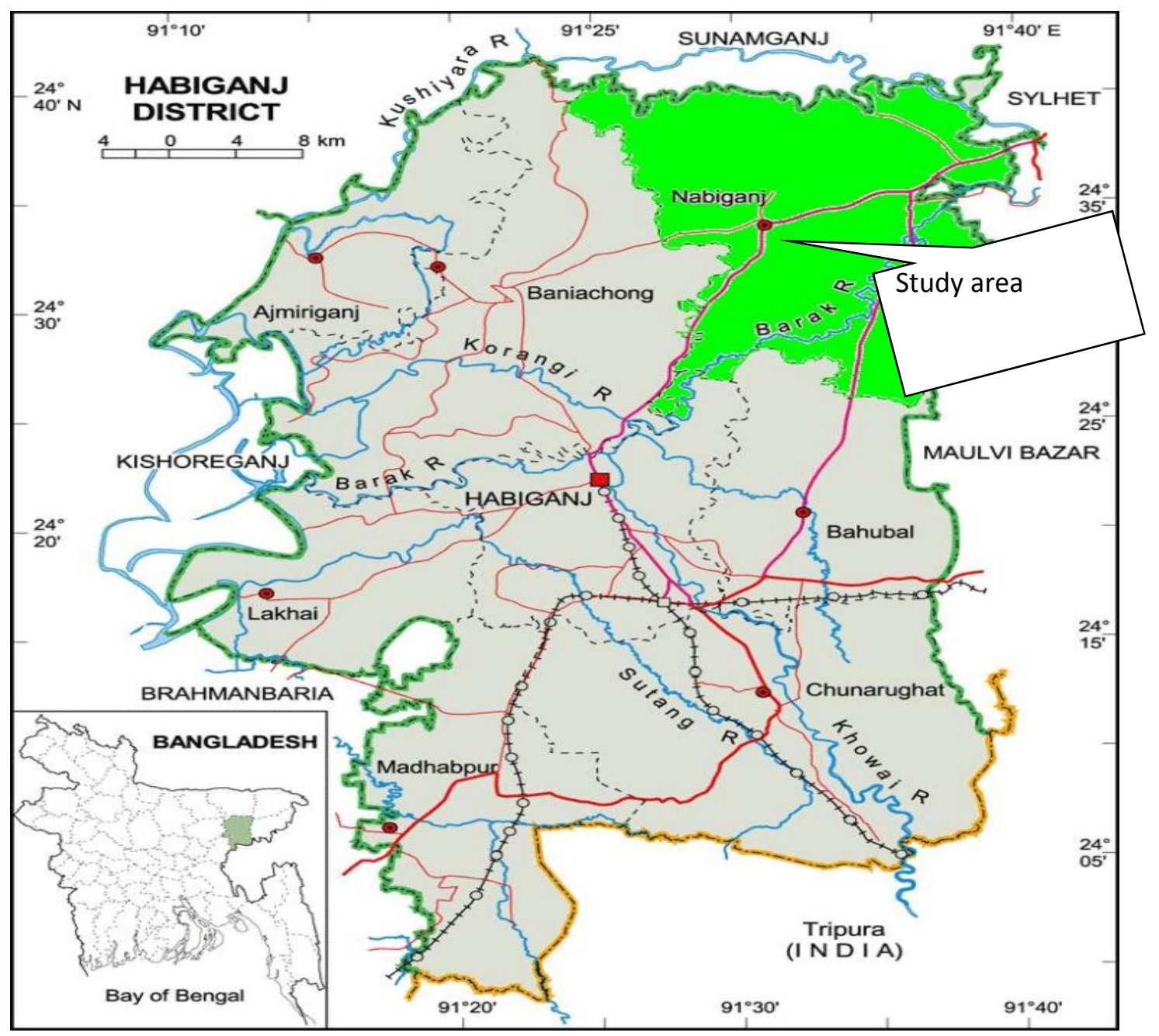

Figure 2. Location of village Nabigonj Municipality of Habigonj on Bangladesh map

\subsection{Data Collection Tools and Technique}

Data were collected during February to March in 2012. Data were collected through face to face interview of respondents and the responses of the respondents were written down on the interview schedule. Both primary and secondary methods of data collection were used.

The data of the study has been collected from both primary and secondary sources. Primary data have been collected through social survey from those respondents, who were mayor, councilors, officials and general people. Two methods were used to collect primary data. These are (a) interview schedule and (b) in-depth interview. The interview schedule was developed by using both open and close ended questions in the questionnaires. Secondary data have been collected from relevant books, municipal budgetary and other financial documents, journals, review notes, published materials and relevant websites etc.

\subsection{Description about the Study Population}

The total number of population of the research is the inhabitants of three wards, the mayor, councilors, and officials of the municipality. The population was drawn from the inhabitants of 3 different wards.

In Ward no. $4=$ total voters no. 1602

In Ward no. $6=$ total voters no. 1063

In Ward no. $9=$ total voters no. 1113

Hence, There is sum total of $=1602+1063+1113=3778$ 


\subsection{Sample and Sampling}

From entire municipal area three wards were purposively selected from 12 wards (one-fourth of the total wards) followed by the categories drawn on the basis of residential location. Secondly, from all voters of three wards, required number of respondents has been selected on basis of simple sampling method.

Table1. Research area and respondents selection process

\begin{tabular}{ll}
\hline Selection of Area & Purposively \\
\hline Selection of Ward $(4,6,9)$ & $\begin{array}{l}\text { Purposively selected the areas due to easy } \\
\text { communication and residential location. }\end{array}$ \\
Selection of Respondents & Simple randomly \\
\hline
\end{tabular}

Following formula has used to find out sample size-

According to Cochran, (1977:75)

$$
\mathrm{n}=\frac{\frac{t^{2} p q}{d^{2}}}{1+\frac{1}{N}\left(\frac{t^{2} p q}{d^{2}}-1\right)}
$$

Here,

$\mathrm{t}=$ definite confidence level $=95 \%=1.9600$

$\mathrm{p}=$ probability success $=0.5$

$\mathrm{q}=$ probability failure that means $1-\mathrm{p}=1-0.5=0.5$

$\mathrm{d}=$ standard error $=10 \%=0.1$

$\mathrm{N}=$ population $=3778$

$\mathrm{n}=$ expected sample size

Sample size $\mathrm{n}=\frac{\frac{t^{2} p q}{d^{2}}}{1+\frac{1}{N}\left(\frac{t^{2} p q}{d^{2}}-1\right)}$

$\mathrm{n}=\frac{\frac{1.96^{2} * 0.5 * 0.5}{0.1^{2}}}{1+\frac{1}{3778}\left(\frac{1.96^{2} * 0.5 * 0.5}{0.1^{2}}-1\right)}=93.68$

$\mathrm{n}=94$

The sample size was 94 which have been taken by using formula of Cochran and the number of the respondents from the sample area is given below on the basis of wards with percentage.

\subsection{Data Processing and Analysis Technique}

The data were characteristically classified and processed both qualitatively and quantitatively. Quantitative analysis was done using statistical tools such as statistical Package for Social Science (SPSS). Both univariate and bivariate analysis was used to analysis of the study.

Pearson Chi-Square $(\chi 2)$ test was used to test the association between independent and dependent variable. Quantitative method was used to generalize and identify prevalence from the data provided by the respondents. Qualitative method was used to explain the significant phenomena, causalities, social realities and experiences. Therefore, both methods complemented each-other in the research. Moreover, some index construction technique has been used to this study. 


\section{Result}

Table 2. Age distribution of respondents

\begin{tabular}{lllll}
\hline Age of Respondents & Frequency & Percent & Valid Percent & Cumulative Percent \\
\hline $21-30$ & 52 & 55.3 & 55.3 & 55.3 \\
$31-40$ & 23 & 24.5 & 24.5 & 79.8 \\
$41-50$ & 13 & 13.8 & 13.8 & 93.6 \\
$51-60$ & 6 & 6.4 & 6.4 & 100.0 \\
Total & 94 & 100.0 & 100.0 & \\
\hline
\end{tabular}

Most of the respondents 55.3 percent were of between 21 to 30 years in age. The highest age of the respondent was 60 years and the lowest age was 21 years.

Table 3. Gender distribution of respondents

\begin{tabular}{ccccc}
\hline Gender of Respondent & Frequency & Percent & Valid Percent & Cumulative Percent \\
\hline Male & 81 & 86.2 & 86.2 & 86.2 \\
Female & 13 & 13.8 & 13.8 & 100.0 \\
\hline
\end{tabular}

In this study most of the respondents were male $(86.2 \%)$ and rest of them were female (13.8\%).

Table 4. Professional distribution of respondents

\begin{tabular}{ccccc}
\hline Profession of the Respondents & Frequency & Percent & Valid Percent & Cumulative Percent \\
\hline Service Holder & 26 & 27.7 & 27.7 & 27.7 \\
Businessman & 42 & 44.7 & 44.7 & 72.3 \\
Farmer & 12 & 12.8 & 12.8 & 85.1 \\
Others & 14 & 14.9 & 14.9 & 100.0 \\
Total & 94 & 100.0 & 100.0 & \\
\hline
\end{tabular}

Maximum respondents were businessman $(44.70 \%)$ and minimum were farmers $(12.80 \%)$. Rests of the respondents were service holder $(27.7 \%)$ and others $(14.90 \%)$.

Table 5. Council consulted the public on setting broad council priorities

\begin{tabular}{lllll}
\hline $\begin{array}{c}\text { Council consulted the public on setting broad council } \\
\text { priorities }\end{array}$ & Frequency & Percent & $\begin{array}{c}\text { Valid } \\
\text { Percent }\end{array}$ & $\begin{array}{c}\text { Cumulative } \\
\text { Percent }\end{array}$ \\
\hline Yes & 50 & 53.2 & 53.2 & 53.2 \\
No & 44 & 46.8 & 46.8 & 100.0 \\
Total & 94 & 100.0 & 100.0 & \\
\hline
\end{tabular}

Most of the respondents (53.2\%) believed that the Council consulted the public on setting broad council priorities and rests (46.8\%) believed that the council didn't consult with people in setting broad council priority. 
Table 6. Public engagement activities ever involved putting draft spending priorities

\begin{tabular}{lllll}
\hline ever involved putting draft spending priorities & Frequency & Percent & Valid Percent & Cumulative Percent \\
\hline Yes & 37 & 39.4 & 39.4 & 39.4 \\
No & 57 & 60.6 & 60.6 & 100.0 \\
Total & 94 & 100.0 & 100.0 & \\
\hline
\end{tabular}

Most of the respondents $(60.6 \%)$ said that there is limitation of public engagement in putting draft spending priorities in their locality and rests $(39.40 \%)$ said that the council engages the public in putting draft spending.

Table 7. Opinion about developing participatory budgeting

\begin{tabular}{lllll}
\hline Council develop any participatory budgeting & Frequency & Percent & Valid Percent & Cumulative Percent \\
\hline Yes & 37 & 39.4 & 39.4 & 39.4 \\
No & 57 & 60.6 & 60.6 & 100.0 \\
Total & 94 & 100.0 & 100.0 & \\
\hline
\end{tabular}

The lion's portion $(60.6 \%)$ of the respondents of the study said that the council didn't develop any participatory budget and the rests (39.4\%) people said that the council did it.

Table 8 . Know about any other public authority in your area that has developed a participatory budgeting

\begin{tabular}{lllll}
\hline Know about any other public authority & Frequency & Percent & Valid Percent & Cumulative Percent \\
\hline Yes & 15 & 16.0 & 16.0 & 16.0 \\
No & 79 & 84.0 & 84.0 & 100.0 \\
Total & 94 & 100.0 & 100.0 & \\
\hline
\end{tabular}

The majority of the respondents $(84.0 \%)$ did not know about any other public authority that hasdeveloped a participatory budgeting and others portion $(16.00 \%)$ were known about the other public authority that developed participatory budgeting.

Table 9. People typically attended budget making

\begin{tabular}{ccccc}
\hline attended in budget making & Frequency & Percent & Valid Percent & Cumulative Percent \\
\hline $1-50$ & 18 & 19.1 & 19.1 & 19.1 \\
$50-99$ & 10 & 10.6 & 10.6 & 29.8 \\
$100-199$ & 13 & 13.8 & 13.8 & 43.6 \\
$200-299$ & 1 & 1.1 & 1.1 & 44.7 \\
$300-500$ & 8 & 8.5 & 8.5 & 53.2 \\
Don't know & 44 & 46.8 & 46.8 & 100.0 \\
Total & 94 & 100.0 & 100.0 & \\
\hline
\end{tabular}

Budget is the blue print through which the demands of the citizens are represented that is why it is essential to involve the general people in setting their priorities but the study revealed that about fifty percent (46.8\%) respondent didn't know how many actually attend in budget making. 
Table 10. Involvement of local people in designing budget

\begin{tabular}{ccccc}
\hline & Frequency & Percent & Valid Percent & Cumulative Percent \\
\hline Yes & 19 & 20.2 & 20.2 & 20.2 \\
No & 55 & 58.5 & 58.5 & 78.7 \\
Don't know & 20 & 21.3 & 21.3 & 100.0 \\
Total & 94 & 100.0 & 100.0 & \\
\hline
\end{tabular}

Table 11. Get invitation to municipal meetings

\begin{tabular}{ccccc}
\hline & Frequency & Percent & Valid Percent & Cumulative Percent \\
\hline Yes & 32 & 34.0 & 34.0 & 34.0 \\
No & 62 & 66.0 & 66.0 & 100.0 \\
Total & 94 & 100.0 & 100.0 & \\
\hline
\end{tabular}

Local government is the instrument for the development of local people but to make a decision about their main concern they were not involved (Table10) and invited by the authority on setting their budget. The above table depict that major part $(66.0 \%)$ of respondent are not invited to the municipal meetings.

Table 12. Supply of adequate information regarding the budget

\begin{tabular}{ccccc}
\hline & Frequency & Percent & Valid Percent & Cumulative Percent \\
\hline Yes & 36 & 38.3 & 38.3 & 38.3 \\
No & 58 & 61.7 & 61.7 & 100.0 \\
Total & 94 & 100.0 & 100.0 & \\
\hline
\end{tabular}

Today is the age of information and now-a-days it is considered as the best weapon to make a job done. The above table confirmed that the municipality didn't provide them adequate information related to budget because 61.7 percent respondents did not get sufficient information related to budget.

Table 13. Opinion about the reflection of needs in the budget

\begin{tabular}{ccccc}
\hline & Frequency & Percent & Valid Percent & Cumulative Percent \\
\hline Yes & 34 & 36.2 & 36.2 & 36.2 \\
No & 60 & 63.8 & 63.8 & 100.0 \\
Total & 94 & 100.0 & 100.0 & \\
\hline
\end{tabular}

Most of the budget of the council is made without the popular participation as a result it failed to focus the needs of general people likely the study found that same, here 63.8 percent respondents said their needs were not reflected by the budget.

Table 14. Opinion about the problem to mobilize and utilize local resources

\begin{tabular}{ccccc}
\hline & Frequency & Percent & Valid Percent & Cumulative Percent \\
\hline Yes & 15 & 16.0 & 16.0 & 16.0 \\
No & 69 & 73.4 & 73.4 & 89.4 \\
No Comments & 10 & 10.6 & 10.6 & 100.0 \\
Total & 94 & 100.0 & 100.0 & \\
\hline
\end{tabular}


Development of a section typically depends on the economic governance that is directly related with the mobilization and utilization of local resources. Most of the respondent (73.4\%) of the study said there is no problem to utilize and mobilize the local resources.

Table 15. Opinion about the ability to identify a part of budget under Participatory budgeting

\begin{tabular}{lcccc}
\hline & Frequency & Percent & Valid Percent & Cumulative Percent \\
\hline Yes & 28 & 29.8 & 29.8 & 29.8 \\
No & 66 & 70.2 & 70.2 & 100.0 \\
Total & 94 & 100.0 & 100.0 & \\
\hline
\end{tabular}

Local people are best known about their particular problem. This table illustrates that greater part (70.2\%) of the respondents were unable to identify a part of their budget which could be allocated under the PB process. On the other hand, participants had the ability to identify a part of their budget which could be allocated under the PB process is 29.8 percent.

Table 16. Opinion about the development of PB in future

\begin{tabular}{ccccc}
\hline & Frequency & Percent & Valid Percent & Cumulative Percent \\
\hline Yes & 80 & 85.1 & 85.1 & 85.1 \\
No & 14 & 14.9 & 14.9 & 100.0 \\
Total & 94 & 100.0 & 100.0 & \\
\hline
\end{tabular}

The table illustrates that nearly all of the $(85.5 \%)$ respondents were positive to develop participatory budgeting in future while only 14.9 percent were not interested to develop such mechanism.

Table17. Opinion about the happiness for the development of PB in future

\begin{tabular}{lllll}
\hline & Frequency & Percent & Valid Percent & Cumulative Percent \\
\hline Yes & 89 & 94.7 & 94.7 & 94.7 \\
No & 5 & 5.3 & 5.3 & 100.0 \\
Total & 94 & 100.0 & 100.0 & \\
\hline
\end{tabular}

The table shows that nearly all the respondents (94.7\%) are happy with initiation of participatory budgeting, while only 5.3 percent are not.

Table 18. Opinion about the improvement of democracy by participatory budgeting

\begin{tabular}{lllll}
\hline & Frequency & Percent & Valid Percent & Cumulative Percent \\
\hline Yes & 71 & 75.5 & 75.5 & 75.5 \\
No & 23 & 24.5 & 24.5 & 100.0 \\
Total & 94 & 100.0 & 100.0 & \\
\hline
\end{tabular}

Democracy is the popular form of government where people can participate easily; participatory budgeting is the form in which people can participate to set their priorities. This table shows that majority $(75.5 \%)$ of the respondent believed that $\mathrm{PB}$ can improve the quality of democracy and rests said (24.5\%) it will not help to improve the quality of democracy. 
Table 19. Opinion about the increasing accountability by participatory budgeting

\begin{tabular}{lllll}
\hline & Frequency & Percent & Valid Percent & Cumulative Percent \\
\hline Yes & 75 & 79.8 & 79.8 & 79.8 \\
No & 19 & 20.2 & 20.2 & 100.0 \\
Total & 94 & 100.0 & 100.0 & \\
\hline
\end{tabular}

The above mentioned table shows that participator budgeting can increase the accountability of public bodies.

Table 20. Scope of participation

\begin{tabular}{llllll}
\hline Items & $\begin{array}{l}\text { Strongly } \\
\text { Agree }\end{array}$ & Agree & Neutral & $\begin{array}{c}\text { Disagree } \\
\end{array}$ & $\begin{array}{l}\text { Strongly } \\
\text { Disagree }\end{array}$ \\
\hline $\begin{array}{l}\text { There has been no proper discussion of PB at } \\
\text { a senior level in our council }\end{array}$ & $48(51.1 \%)$ & $24(25.5)$ & $14(14.9)$ & $5(5.3)$ & $3(3.2)$ \\
$\begin{array}{l}\text { We've had no earlier experience of PB or } \\
\text { similar budgetary mechanisms }\end{array}$ & $37(39.4)$ & $36(38.3)$ & $18(19.1)$ & $3(3.2$ & $0(0)$ \\
$\begin{array}{l}\text { There is a lack of awareness and } \\
\text { understanding of PB within the council }\end{array}$ & $64(68.1)$ & $16(17.0)$ & $8(8.5)$ & $6(6.4)$ & $0(0)$ \\
$\begin{array}{l}\text { We've considered PB, but there is a lack of } \\
\text { enthusiasm }\end{array}$ & $65(69.1)$ & $23(24.5)$ & $5(5.3)$ & $1(1.1)$ & $0(0)$ \\
$\begin{array}{l}\text { There are worries about cost } \\
\text { There are worries about complexity }\end{array}$ & $12(12.8)$ & $31(33.0)$ & $40(42.6)$ & $10(10.6)$ & $1(1.1)$ \\
There is uncertainty about gains & $14(14.9)$ & $23(24.5)$ & $43(45.7)$ & $11(11.7)$ & $3(3.2)$ \\
\hline
\end{tabular}

Local Government is an important development partner of the developing world where local budgeting is a tool for engaging local people in this development force. However the study revealed that we didn't have such experience (Table20) earlier even we didn't discuss about it within our jurisdiction. The study found (Table 20) that there is lack of awareness and understanding of PB that is why the respondent did not found any complexity at budget making in their locality. As Bangladesh is a resource poor country, we always have to face the challenges and have uncertainty to attain the objectives of our development projects, likely so the research found the same. Enthusiasm is an imperative part to initiate participatory budgeting but we found that there is lack of enthusiasm to develop a participatory budgeting (Table 20).

After analyzing the above reasons relevant to participatory budgeting we can see the scope of participation is as follows.

Table 21. Level of scope of participations

\begin{tabular}{llllll}
\hline Range & level & Frequency & Percent & Valid Percent & Cumulative Percent \\
\hline $5-14$ & Low & 33 & 35.1 & 35.1 & 35.1 \\
$15-24$ & middle & 46 & 48.9 & 48.9 & 84.0 \\
$25-35$ & high & 15 & 16.0 & 16.0 & 100.0 \\
& Total & 94 & 100. & 100.0 & \\
\hline
\end{tabular}

Aboutthirty five percent (35.1\%) of the respondents of the study believe that the scope of participation in budget making was low and less than fifty percent (48.9\%) respondents believed that the scope was medium to participate in municipal budget making. 
Table 22. Perception towards participatory budgeting

\begin{tabular}{llllll}
\hline Items & $\begin{array}{l}\text { Strongly } \\
\text { Agree }\end{array}$ & Agree & Neutral & Disagree & $\begin{array}{l}\text { Strongly } \\
\text { Disagree }\end{array}$ \\
\hline $\begin{array}{l}\text { The PB engages well with different sections } \\
\text { of the community }\end{array}$ & $67(71.3)$ & $22(23.4)$ & $1(1.1)$ & $3(3.2)$ & $1(1.1)$ \\
$\begin{array}{l}\text { Participants in the PB are representative of } \\
\text { the wider community }\end{array}$ & $30(31.9)$ & $49(52.1)$ & $12(12.8)$ & $2(2.1)$ & $1(1.1)$ \\
$\begin{array}{l}\text { Participants in the PB are positive about the } \\
\text { experience }\end{array}$ & $58(61.7)$ & $23(24.5)$ & $5(5.3)$ & $8(8.5)$ & $0(0.0)$ \\
$\begin{array}{l}\text { Councilors are broadly positive about the PB } \\
\text { project }\end{array}$ & $12(12.8)$ & $10(10.6)$ & $7(7.4)$ & $52(55.3)$ & $13(13.8)$ \\
\hline
\end{tabular}

Development is a comprehensive term which requires the attachment of different sections of community to accelerate the process. The study expose that lion's segment (71.3\%) of respondent has strongly agreed and 23.4 percent has agreed with the avowal that PB engages well with different sections of the community where 1.1 percent disagree with it. Participatory budget engage different section of community that is why it is representative of the wider community of people of the regime. The table shows that more than fifty percent $(52.1 \%)$ respondents were agreed where 31.9 percent were strongly agreed. This table shows that participants were broadly positive with the practice because 61.7 percent respondents were strongly agreed on the other hand only 8.5 percent respondentswere disagreed with the declaration. Representatives (councilors) have to play the vital role to carry out the participatory budgeting but the study exposed that the councilors were not positive with it. Most of the respondents $(55.3 \%)$ were disagreed with the assertion. From the above discussion now we look at the distribution about the perception of participatory budgeting.

Table 23. Perception towards participatory budgeting

\begin{tabular}{clllll}
\hline Range & Level & Frequency & Percent & Valid Percent & Cumulative Percent \\
\hline $4-9$ & positive & 52 & 55.3 & 55.3 & 55.3 \\
$11-15$ & middle & 31 & 33.0 & 33.0 & 88.3 \\
$16-20$ & negative & 11 & 11.7 & 11.7 & 100.0 \\
& Total & 94 & 100.0 & 100.0 & \\
\hline
\end{tabular}

The table exhibits that leading section $(55.3 \%)$ of respondent was highly positive towards the participatory budgeting while only 11.7 percent respondents were negative with the statement.

Table 24. Scope of participation and council develop any participatory budgeting

\begin{tabular}{lllllllllll}
\hline \multicolumn{1}{c}{ Council develop any participatorybudgeting } & \multicolumn{1}{c}{ Scope of Participation } \\
\hline & Low & & middle & high & \multicolumn{1}{l}{ total } \\
\hline & $\mathrm{n}$ & $\%$ & $\mathrm{n}$ & $\%$ & $\mathrm{n}$ & $\%$ & $\mathrm{n}$ & $\%$ \\
\hline YES & 9 & 27.3 & 18 & 39.1 & 10 & 66.7 & 37 & 39.4 \\
NO & 24 & 72.7 & 28 & 60.9 & 5 & 33.3 & 57 & 60.6 \\
Total & 33 & 100.0 & 46 & 100.0 & 15 & 100.0 & 94 & 100.0 \\
\hline
\end{tabular}

$\chi^{2}=6.707 \mathrm{df}=2, \mathrm{P}$ value $=0.035$

The Scope of Participation is positively associated with the development of participatory budgeting by the council. The results shows that Council develop any participatory budget was lower (27.3) among the respondents who had low scope of participations. The study revealed that (Table 24) the increasing rate of PB at local level influence the rate of participation in local budget and other decision making at local government level. 
The Chi-square test also shows the association betweenscope of participation and council develop any participatory budgeting council is significant.

Table 25. Perception towards participatory budgeting and council develop any participatory budgeting

\begin{tabular}{llllllllll}
\hline Council develop any participatory budgeting & \multicolumn{6}{l}{ Perception towards participatory budgeting } & & \\
\hline & Positive & \multicolumn{2}{l}{ middle } & negative & \multicolumn{2}{l}{ Total } \\
\hline & $\mathrm{n}$ & $\%$ & $\mathrm{n}$ & $\%$ & $\mathrm{n}$ & $\%$ & $\mathrm{n}$ & $\%$ \\
\hline Yes & 27 & $51.9 \%$ & 6 & $19.4 \%$ & 4 & $36.4 \%$ & 37 & $39.4 \%$ \\
No & 25 & $48.1 \%$ & 25 & $80.6 \%$ & 7 & $63.6 \%$ & 57 & $60.6 \%$ \\
& 52 & $100.0 \%$ & 31 & $100.0 \%$ & 11 & $100.0 \%$ & 94 & $100.0 \%$ \\
\hline
\end{tabular}

$\chi^{2}=8.678 \mathrm{df}=2$, P value $=0.013$

The Perception of respondents towards participatory budgeting is positively associated with the development of participatory budgeting. The results shows that council develop any participatory budget was lower (36.4\%) among the respondents who had negative perception towards participatory budgeting. Respectively, respondents that had middle perception towards participatory budgeting was $19.4 \%$ Council develop any participatory budgeting and respondents that had positive perception towards participatory budgeting have 51.9\% Council develop any participatory budgeting. The Chi-square test also shows the association betweenScope of Participation and Council develop any participatory budgeting Council is significant.

\subsection{Qualitative Analysis}

Participatory budgeting is promising as a pioneering urban management practice with tremendous potential to boost up the principle of good governance. In fact, participatory budgeting can yield many paybacks to local government and civil society alike. It can improve transparency in municipal expenditures and stimulate citizens' involvement in decision-making over public funds. It can forward municipal investment toward basic infrastructure for poorer neighborhoods and strengthen social networks and help mediate differences between elected leaders and civil society groups.

Municipality (as local government unit) can play a decisive role to make a budget with popular participation, from formulating the priorities to the implementation of decisions. The local government body facilitates the process, while the mayor legitimizes it politically. In addition, the local government also acts as protagonist with the liability to create mechanisms that ensure a holistic vision of the problems and needs of the municipality. But the Nabigonj municipality had not take such an initiative in budget making however they took some sort of public opinion in broad priority setting. Participatory budgeting is new style of modern governance, while the extent of popular participation of our administration in various stages hardly prevailing, it will create the scope of effective participation for the localities in setting their needs. Mia Mohammadfrom Nabigonj Municipality said that

'Thirteen years have gone, the municipality has established but where is the light, where

is the drain, where is the road."

The awareness and understanding about participatory budgeting is not satisfactory because the citizens have not the earlier experience about participatory budgeting. Moreover there is no proper discussion of PB at senior level (mayor \& councilors) of the municipality that may prove that there is a lack of enthusiasm among them however all of them took training regarding to local governance. Development projects required extensive level of popular participation when it will not happen that create complexity and fail to achieve the desire outcomes thus the community worried about the cost.

Every fiscal year make a budget but many people does not know how many years cover a budget and about the availability of fund. The municipality provides a number of facilities like; street cleaning and recycling, road maintenance, education, community policing, sanitation, drainage, bus terminal maintenance, graveyards etc. But many of them is not properly distributes among the citizens of the municipality however according to the councilors they always try to provide all the facilities but the scenario is not equal to local authority wide.

The municipality is going to start a school and they provide scholarship to the meritorious students every year and the freedom fighter are exempt of all taxes these two are the best initiatives of municipality that must be 
given extra praise and it also an example of a benevolent authority. Razu Uddin from Nabigonj Municipality said that

"I do pay all my taxes regularly but Char Gao (a village of Nabigonj) gets the better opportunity but we don't."

Most of people do not have the idea who is invited to participate in budgeting in fact the municipality announced before the budget declaration; it is the step where people somehow get the opportunity to involve but it is a one way involvement. One female councilor of the municipality said she has no scope to participate in decision making process of the municipality that proves the reality of the municipality that exists.

The traditional budget is a process that preserve of municipal officials led by the treasurer or accountant; the participatory budgeting concerns citizens involved in identification of needs and priorities to implementation, monitoring and evaluation. The preferred outcome of the participatory budgeting system is to provide citizens with an opportunity to participate in the financial decision-making process of the local authority. Local peoples are broadly positive about the experience whereas the councilors are not positive about experience. In participatory budgeting peoples are representative of the wider community and it engages well with different sections of the community that is why it helps to reflect the demand of majority population which is hardly reflected in Nabigonj municipal budget.

Every individual has the absolute right to life, liberty and the security of person. Insecurity has an uneven impact in further marginalizing poor communities for this reason community policing system is going on within the municipality.

Municipality must strive to avoid human conflicts and natural disasters by involving all stakeholders in crime and conflict prevention and disaster preparedness which is absent.

The Central government is an important apparatus that can play a vital role to make a budget participatory from national level to local level that is why higher profile commitment from national government to participatory budgeting is essential. To access information is indispensable to this understanding and good governance. Accountability is a basic principle of good urban governance of local authorities and all service providers to their citizens. Thus eventually enhance the quality of democracy as a participative manner.

\section{Discussion}

These section summaries the main findings of the study which reveals an understanding of participatory budgeting as a concept that leads to improve governance is still very limited within the Nabigonj Municipality.

The Municipality has not taken various initiatives in terms of improving citizen participation in the municipal decision-making processes even there is no discussion at a senior level of the council about participatory budgeting. Although municipal leaders argued that they were trying all they could to encourage citizens to participate in the municipal decision-making processes, citizens did not share the same opinion. This means that the Nabigonj Municipality is not supporting to improve the quality of democracy.

Participatory budgeting has been recognized as a significant and successful experience of promoting decentralized participatory development in various part of the world. Although there have been great promises in terms of the promotion of participatory development, budgeting included, the study of the Nabigonj Municipality expose that actual outcomes to date have been frustrating from the budget that they made.

If the institutions have been carefully designed and properly scaled, thus resulting in more opportunities for citizens and the marginalized groups to participate and enjoy their citizenship rights that indicate there is a lack of institutional framework.

By engaging citizens in the budget making process, municipal councilors had to change an earlier complicated budget process into a more clearer and transparent budget. The fact that neighborhood meetings were most of the time supplemented by the creation of a group to discuss broader municipal issues suggests that this had a learning effect. The participation on budget issues that do not occur, both to the infrastructure and the operational budget and day-to-day issues are discussed and decided. It might, therefore, not be presumptuous to conclude that municipal staff enjoy holding on to power and final decision-making.

\section{Conclusion}

Notwithstanding constitutional promise of ownership of the Republic by citizens of the country, the decision-making power has always been outside the sphere of the common people. The rules and procedures have not been reformed in the light of this citizen proprietorship. Therefore, hopes and aspirations of citizens get hardly reflected in the development agenda of the government, both national and local. 
Participation is not sufficient in every sphere and it fails to involve meaningful dialogue that affects public decision making. Civil society can play an imperative role in improving participation. In the light of the previous findings, it is obvious that in the context of the Nabigonj Municipality, it is not clear what the participation process is meant to achieve. The study found that citizens incapable of contributing productively to policy-making. Below, a number of policy requirements for successful implementation of a participatory budgeting process are highlighted. Political will from the ground of national and local level government. Local politicians must feel that broader participation resolves their problem through identifying resources.

1) Establishment of appropriate institutional structure of local authority with flexible and legal framework for local government budgeting process and the number and the diversity of the population.Involvement of citizen from initial stage of budget design through dialogue because early engagement of citizens in the municipal budgeting process is likely to be more effective in influencing decisions, building trust and reducing skepticism about municipalities, empowering citizens.

2) Raising awareness and understanding about participatory budgeting through innovative communications such as the organizing civic meetings, use of cartoons and popular language. Attention is given to using a variety of media to communicate including local radio and the internet. Publicity is very important to disseminate information. Creating an attractive style for communicating about participatory budgeting is needed to make people aware of how to participate. Local newspapers and use of council newsletters to communicate directly with residents.

\section{References}

Canel, E. (2001). Municipal Decentralization and Participatory Democracy: Building a New Mode of Urban Politics in Montevideo City? European.Review of Latin American and Caribbean Studies, 71, 25-46.

Chadha, S. (1989). Managing Project in Bangladesh. University Press Limited, Dhaka 1000, Bangladesh.

Heimans. J. (2002). Strengthening Participation In Public Expenditure Management: Policy Recommendations for Key Stakeholders.The Organization For Economic Co-operationand Development. Retrieved from http://www.oecd.org/pdf/M00037000/M00037848.pdf

Human Development Report. (1993). United Nations Development Programs. New York.

Ministry of Local Government. (2002). The Republic of Uganda, Guide toParticipatory Planning for Lower Local Councils. Retrieved from http://www.khanya-aicdd.org/Publications/CBP_HPPG_2002.pdf

Murdia, R. N. (2005). Participatory Rural Governance in India: A myth or reality, Paper presented at the Conference on The Role of PublicAdministration in Building a Harmonious Society to be held in Beijing, China.

Nieuwland, H. T. (2003). Participatory Budgeting in Canadian Cities. Retrieved from http://home.oise.utoronto.ca/ daniel_schugurensky/courses/2003_nieuwland.Pdf

Rios, J., \& Rios, D. (2005). Participatory Budget Formation through the Web. In M. Bohlen et al. (Eds.), TCGOV 2005, LNAI $3416 . \quad$ Retrieved from http://presupuesto_participativo.mef.gob.pe/portal_pp/Docs/Boletines/Participatory_Budget_web.Pdf

Rios, J., \& Rios, I. D. (2008).A framework for participatory budget elaboration support. Journal of the Operational Research Society, 59, 203-212. http://dx.doi.org/10.1057/palgrave.jors.2602501

Robson, C. (1993). Real World Research: A Resource for Social Scientists and Practitioners. Oxford: Blackwell.

Santos, B. S. (1998). Participatory Budgeting in Porto Alegre: Toward a Redistributive Democracy. Politics \& Society, 26(4), 461-510. http://dx.doi.org/10.1177/0032329298026004003

Shah, A. (2007). Participatory Budgeting. Washington, DC: IBRD World Bank. http://dx.doi.org/10.1596/978-0-8213-6923-4

Sintomer, Y., Herzberg, C., \& Rocke, A. (2008).Participatory budgeting in Europe: Potentials and challenges. Int. Jour. Ur. Reg. Research, 32(1), 164-178. http://dx.doi.org/10.1111/j.1468-2427.2008.00777.x

Srinivasan, R. (2006). Participatory Budgeting: Toolkit for Local Governments in Albania. Social Development Team Europe and Central Asia Region. Retrieved from http://siteresources.worldbank.org/INTALBANIA/Resources/PBP_Toolkit_Dec_06_Eng.pdf

United Nations. (2005). Participatory Planning and Budgeting at the Sub-national Level. United Nations Publication, Printed in Manila, Philippine. Retrieved from 
http://www.unpan.org/Portals/0/60yrhistory/documents/Publications/Participaory\%20Planning\%20and\%20 Budgeting.2005.pdf

Van Zyl, C. (2005). Optimum Market-Positioning Models for South African Arts Festival Scenarios. Unpublished PhD Thesis. Pretoria: University of South Africa.

Vergara. V. M. (2002). Participatory municipal budgeting as a tool to establish accountable governance. World Bank Institute, May.

Virapatirin, M., \& Peixoto, T. (2006). The white book on local e-democracy. Retrieved from http://www.forum-edemo.org/IMG/pdf/livre_Blanc_Anglais.pdf

World Bank. (2006). Europe \& Central Asia Experience Participatory Budgeting a Toolkit for Local

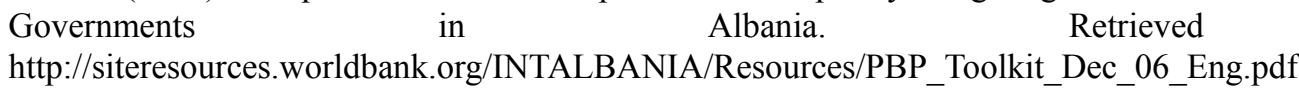

\section{Copyrights}

Copyright for this articles retained by the author(s), with first publication rights granted to the journal.

This is an open-access article distributed under the terms and conditions of the CreativeCommons Attribution license (http://creativecommons.org/licenses/by/3.0/). 